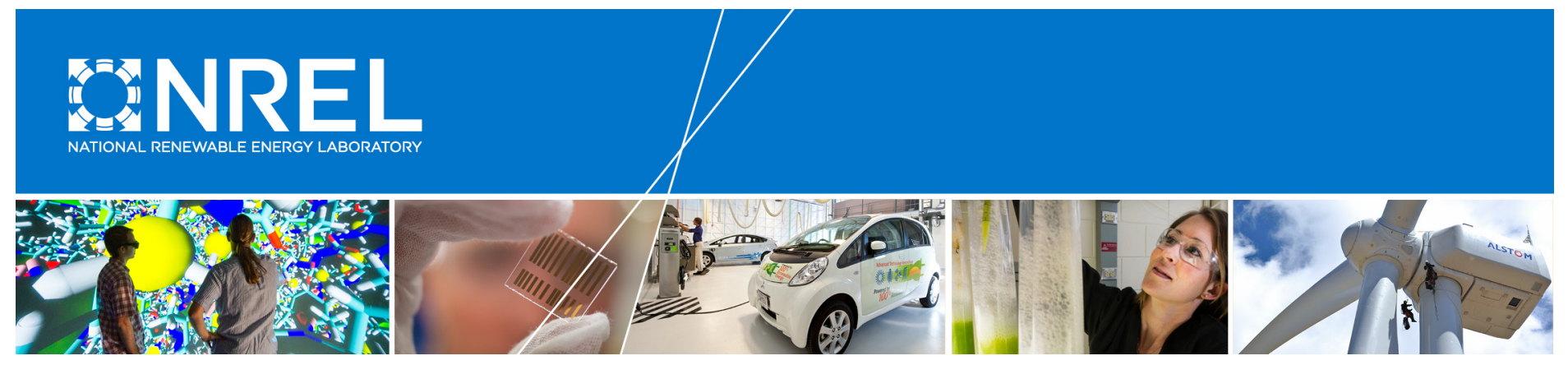

\title{
Analyzing the Energy Performance, Wind Loading, and Costs of Photovoltaic Slat Modules on Commercial Rooftops
}

Otto VanGeet, Ran Fu, Kelsey Horowitz, Parthiv Kurup, Sara MacAlpine, and Timothy J. Silverman National Renewable Energy Laboratory

NREL is a national laboratory of the U.S. Department of Energy Office of Energy Efficiency \& Renewable Energy Operated by the Alliance for Sustainable Energy, LLC

This report is available at no cost from the National Renewable Energy Laboratory (NREL) at www.nrel.gov/publications.

Technical Report

NREL/TP-7A40-70681

February 2018 


\section{Analyzing the Energy Performance, Wind Loading, and Costs of Photovoltaic Slat Modules on Commercial Rooftops}

Otto VanGeet, Ran Fu, Kelsey Horowitz, Parthiv Kurup, Sara MacAlpine, and Timothy J. Silverman National Renewable Energy Laboratory

Prepared under Task No(s). SETP.10300.70.01.00

NREL is a national laboratory of the U.S. Department of Energy Office of Energy Efficiency \& Renewable Energy Operated by the Alliance for Sustainable Energy, LLC

This report is available at no cost from the National Renewable Energy Laboratory (NREL) at www.nrel.gov/publications.

National Renewable Energy Laboratory 15013 Denver West Parkway Golden, CO 80401

303-275-3000 • www.nrel.gov

\section{Technical Report}

NREL/TP-7A40-70681

February 2018

Contract No. DE-AC36-08GO28308 


\title{
NOTICE
}

This report was prepared as an account of work sponsored by an agency of the United States government. Neither the United States government nor any agency thereof, nor any of their employees, makes any warranty, express or implied, or assumes any legal liability or responsibility for the accuracy, completeness, or usefulness of any information, apparatus, product, or process disclosed, or represents that its use would not infringe privately owned rights. Reference herein to any specific commercial product, process, or service by trade name, trademark, manufacturer, or otherwise does not necessarily constitute or imply its endorsement, recommendation, or favoring by the United States government or any agency thereof. The views and opinions of authors expressed herein do not necessarily state or reflect those of the United States government or any agency thereof.

This report is available at no cost from the National Renewable Energy Laboratory (NREL) at www.nrel.gov/publications.

Available electronically at SciTech Connect http:/www.osti.gov/scitech

Available for a processing fee to U.S. Department of Energy and its contractors, in paper, from:

\author{
U.S. Department of Energy \\ Office of Scientific and Technical Information \\ P.O. Box 62 \\ Oak Ridge, TN 37831-0062 \\ OSTI http://www.osti.gov \\ Phone: 865.576.8401 \\ Fax: 865.576.5728 \\ Email: reports@osti.gov
}

Available for sale to the public, in paper, from:

\author{
U.S. Department of Commerce \\ National Technical Information Service \\ 5301 Shawnee Road \\ Alexandria, VA 22312 \\ NTIS http://www.ntis.gov \\ Phone: 800.553 .6847 or 703.605 .6000 \\ Fax: 703.605.6900 \\ Email: orders@ntis.gov
}




\section{List of Acronyms and Abbreviations}

Al

ASCE

BOS

c-Si

DC

DFMA

HFB

j-box

LCOE

NREL

OD

PERC

PMMA

PV

SAM

SEAOC

SEI

$\mathrm{t}$

UV aluminum

American Society of Civil Engineers

balance of system

crystalline silicon

direct current

Design for Manufacturing and Assembly

high-frequency balance

junction box

levelized cost of energy

National Renewable Energy Laboratory

outer diameter

passivated emitter and rear cells

polymethyl methacrylate

photovoltaic(s)

System Advisor Model

Structural Engineers Association of California

Structural Engineering Institute

thickness

ultraviolet 


\section{Executive Summary}

The National Renewable Energy Laboratory (NREL) has developed an innovative new photovoltaic (PV) module for mounting on flat rooftops called "PV Slat module."

In NREL's PV Slat module design, multiple narrow, tilted slats are mounted in a single frame. Each slat contains one row of PV cells made using ordinary crystalline silicon (c-Si) PV module materials and processes. This design is meant to reduce wind loading compared with the loading experienced by conventional module designs, enabling the slats to be tilted at higher angles while remaining relatively lightweight and avoiding high balance of system (BOS) costs. In addition, because shadows have less impact on PV Slat modules than they do on conventional modules, the spacing between rows of slat modules can be smaller and relative energy generation higher. This report quantifies the potential benefits of PV Slat modules in terms of energy performance, wind loading, installed-system costs, and levelized cost of energy (LCOE).

Under most simulated conditions, a conventional system and a smaller-capacity slat system produce the same annual energy yield. This means that the slat system requires a smaller number of modules to generate equivalent energy.

Based on wind tunnel testing of scale building and PV system models, PV Slat modules installed in the corners (Zone 3) and along the sides between two corners (Zone 2) of flat rooftops incur relatively low wind loading. Compared with the American Society of Civil Engineers (ASCE) design code for allowable wind load acting on ballasted rooftop PV arrays, wind loading is 10\% lower for slat modules installed in Zone 3 and 41\% lower for slat modules installed in Zone 2. This lower wind loading could reduce ballast weight requirements commensurately, which —in addition to reducing system costs - could enable PV installation on weight-constrained commercial rooftops without the need for roof-penetrating mounts.

Finally, cost modeling shows that the PV Slat design's performance advantages can translate into cost savings. Although the per-watt cost for slat modules is higher than for conventional c-Si modules in our analysis, this premium is more than offset on an installed-cost basis by the slat system's lower BOS, labor, and other (overhead, profit, sales tax) costs. In combination with the slat system's higher performance, the lower installed cost results in lower LCOEs, as shown in Table ES-1. Although there is considerably more uncertainty associated with the novel slat module and system costs than with the incumbent module technology costs, this analysis suggests that the slat module design could be cost-effective on both an installed-cost basis and an LCOE basis.

Table ES-1. Summary of LCOE Results for a 200-kW Commercial Rooftop System in Kansas City

\begin{tabular}{|c|c|c|c|c|}
\hline Module Design & $\begin{array}{l}\text { First Year Energy } \\
\text { Yield (kWh/kW(DC) }\end{array}$ & $\begin{array}{l}\text { Capacity } \\
\text { Factor }\end{array}$ & $\begin{array}{l}\text { Total Installed } \\
\text { System Cost }\left(\$ / W_{(D C)}\right)\end{array}$ & $\begin{array}{l}\text { Nominal LCOE } \\
\text { ( } \phi / \mathrm{kWh})\end{array}$ \\
\hline $\begin{array}{l}\text { Baseline/Standard } \\
\text { c-Si PERC }\end{array}$ & 1,415 & $16.15 \%$ & $\$ 1.80$ & 14.08 \\
\hline $\begin{array}{l}\text { Slat Module (all in } \\
\text { Zone 3) }\end{array}$ & 1,448 & $16.43 \%$ & $\$ 1.77$ & 13.57 \\
\hline $\begin{array}{l}\text { Slat Module (all in } \\
\text { Zone 2) }\end{array}$ & 1,448 & $16.43 \%$ & $\$ 1.75$ & 13.45 \\
\hline
\end{tabular}




\section{Table of Contents}

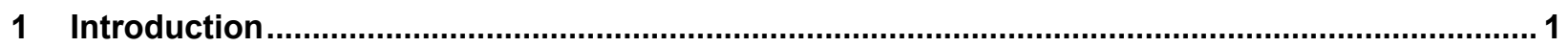

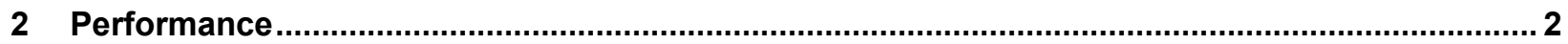

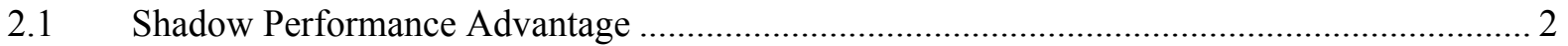

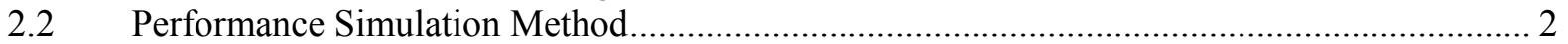

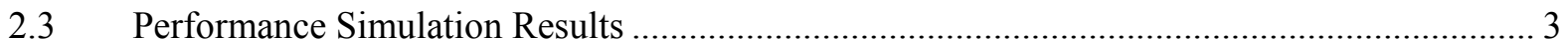

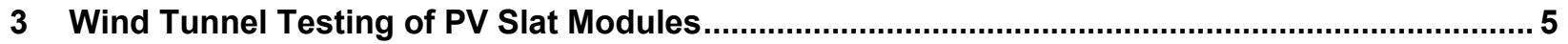

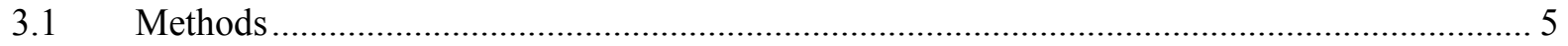

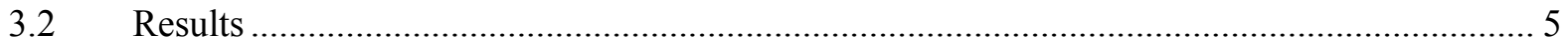

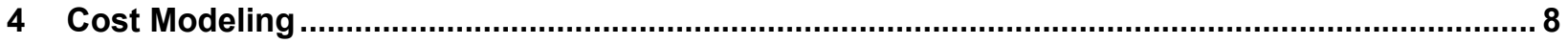

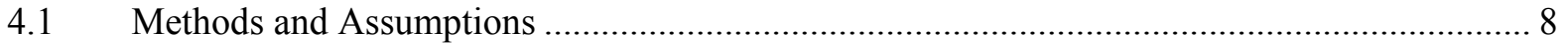

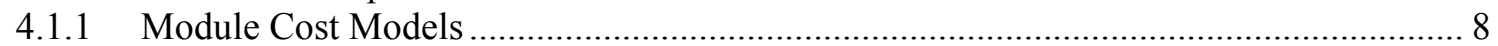

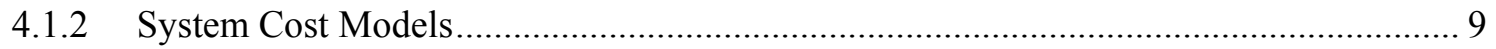

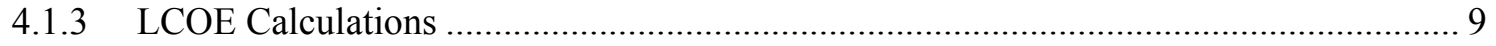

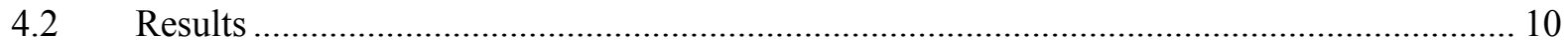

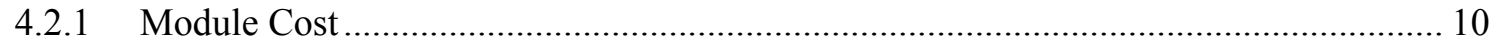

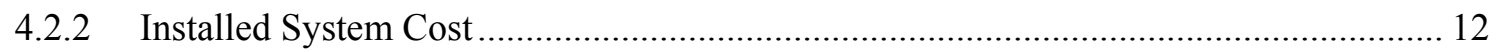

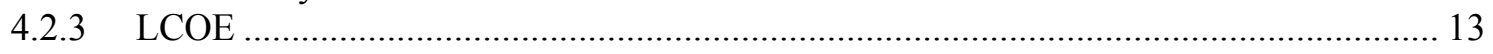

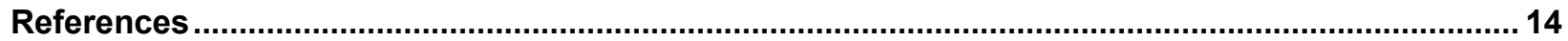




\section{List of Figures}

Figure 1. Artist's rendering of a PV Slat module 1

Figure 2. Shadow performance comparison of conventional module and PV Slat module, with red denoting cells rendered inactive because their bypass diode is activated.....

Figure 3. Simple diagrams of a subsample of simulated system geometries, showing the tilt angle and relative spacing for a range of candidate systems ................................................................ 3

Figure 4. Capacity discount for a tilt- and spacing-optimized slat module system, as a function of conventional system size with $5^{\circ}$ tilt and spacing optimized for a fixed building size............ 4

Figure 5. Example conventional systems with $5^{\circ}$ tilt and spacing optimized for a fixed building size compared with tilt- and spacing-optimized slat systems that produce the same amount of energy as the conventional systems but with smaller capacities, in Kansas City .....

Figure 6. Three-dimensional model of slat module (left) and physical model used in wind tunnel test

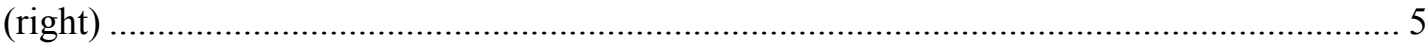

Figure 7. Roof zones, all wind directions from CPP (2017) Figure 3-1 .............................................. 6

Figure 8. Lift coefficient $\left(\mathrm{GC}_{\mathrm{L}}\right)$ of PV Slat (NREL) modules a function of normalized wind area (CPP

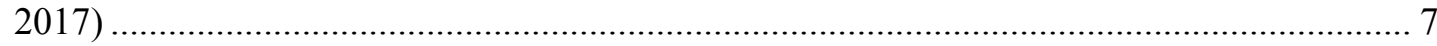

Figure 9. Overall dimensions for PV Slat frame used in manufacturing analysis (in millimeters) ............. 8

Figure 10. Computer-aided design model (left) and general dimensions for aluminum (Al) PV Slat supports (in millimeters) ............................................................................................ 9

Figure 11. Step-by-step manufacturing costs for the slat module assembly (with the all-metal structure) using monocrystalline PERC solar cells, assuming 500-MW annual production volume and manufacturing in urban China, $72\left(239 \mathrm{~cm}^{2}\right)$ PERC cells at $21.5 \%$ efficiency, $350 \mathrm{~W}$ per module.

\section{List of Tables}

Table ES-1. Summary of LCOE Results for a 200-kW Commercial Rooftop System in Kansas City .........ii Table 1. Lift Coefficients and Corresponding Forces Acting on Slat Modules in Wind Tunnel Test, with

Comparison to ASCE Design Code

Table 2. Summary of Slat Structure Manufacturing Costs for Two Different Structure Options (not

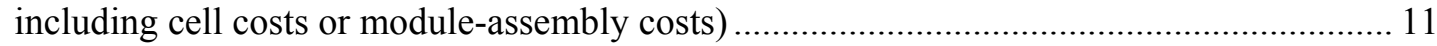

Table 3. Installed System Costs for a 200-kW Commercial Rooftop System in Kansas City................... 13

Table 4. Summary of LCOE Results for a 200-kW Commercial Rooftop System in Kansas City ............ 13 


\section{Introduction}

Conventional ballasted photovoltaic (PV) modules for flat roofs - such as those on commercial buildings - present design tradeoffs. Tilting the modules at a higher angle increases per-module energy production by increasing the intensity of the sunlight that enters the modules, but it reduces the system's energy-generation capacity because rows of modules must be spaced farther apart to prevent the rows from shading each other excessively. Higher tilt angles also increase the wind loads acting on the modules, which increases balance of system (BOS) costs owing to additional ballast requirements. Many flat-roof systems use a tilt of $5^{\circ}$, which is far from the optimal angle for energy production in most locations.

In part to address these tradeoffs, the National Renewable Energy Laboratory's (NREL's) Otto Van Geet invented the PV Slat module concept in 2009 (Figure 1). ${ }^{1}$ In this design, multiple narrow, tilted slats are mounted in a single frame. Each slat contains a single row of PV cells made using ordinary crystalline silicon (c-Si) PV module materials and processes, including a glass front sheet and weatherproof polymer packaging. This design is meant to reduce wind loading, enabling the slats to be tilted at angles greater than $5^{\circ}$ while remaining relatively lightweight and avoiding high BOS costs. In addition, because shadows have less impact on the single-cell rows of PV Slat modules than they do on conventional modules (described in Section 2.1), the spacing between rows of slat modules can be smaller and energy generation higher.

This report analyzes the potential for PV Slat modules to offer higher performance and lower cost compared with conventional module designs. Section 2 compares the simulated energy performance of the two module types, Section 3 describes wind tunnel testing of the modules, and Section 4 examines modeled module and installed-system costs as well as levelized cost of energy (LCOE) results.

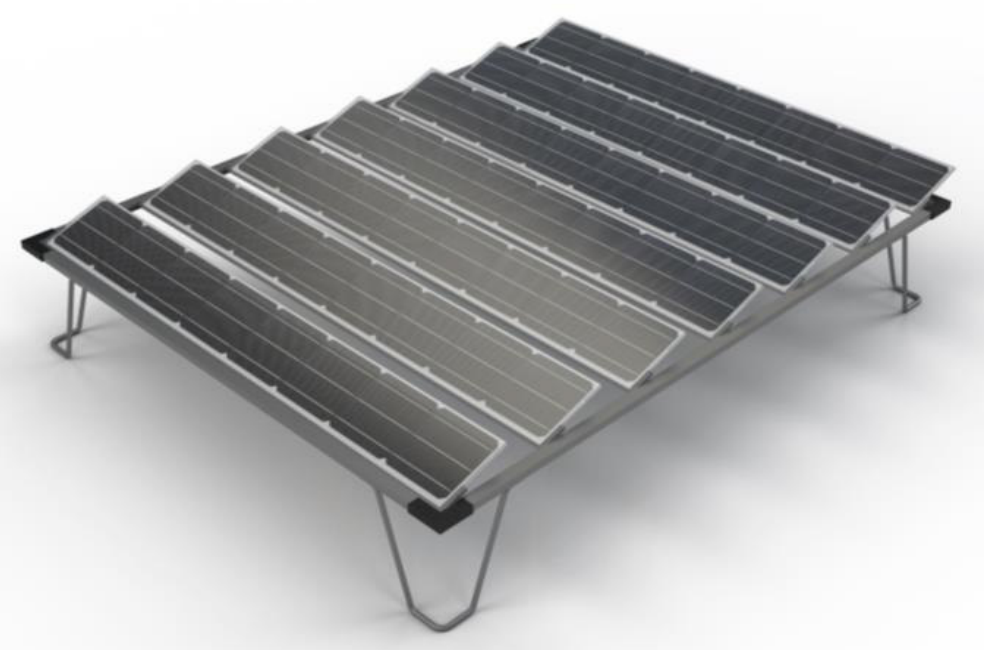

Figure 1. Artist's rendering of a PV Slat module

\footnotetext{
${ }^{1}$ NREL Record of Invention ROI-15-41.
} 


\section{Performance}

This section describes the methods used to analyze the energy performance of the modules as well as the simulation results.

\subsection{Shadow Performance Advantage}

Tilted PV modules installed in repeating rows can be subject to shadows cast from one row onto the next. These row-to-row shadows cause illumination mismatch between cells. Conventional modules have bypass diodes that each can disable one third of the module owing to this mismatch. The level of mismatch required to activate a bypass diode depends on the details of the solar cell, but a shadow covering roughly one sixth of a conventional module can cause a reduction in output of one third. As shown in Figure 2, row-to-row shadows cause every cell in a slat module to be equally illuminated, so bypass diodes do not impair performance. A row-torow shadow covering a certain fraction of a slat's area reduces output by less than that fraction.

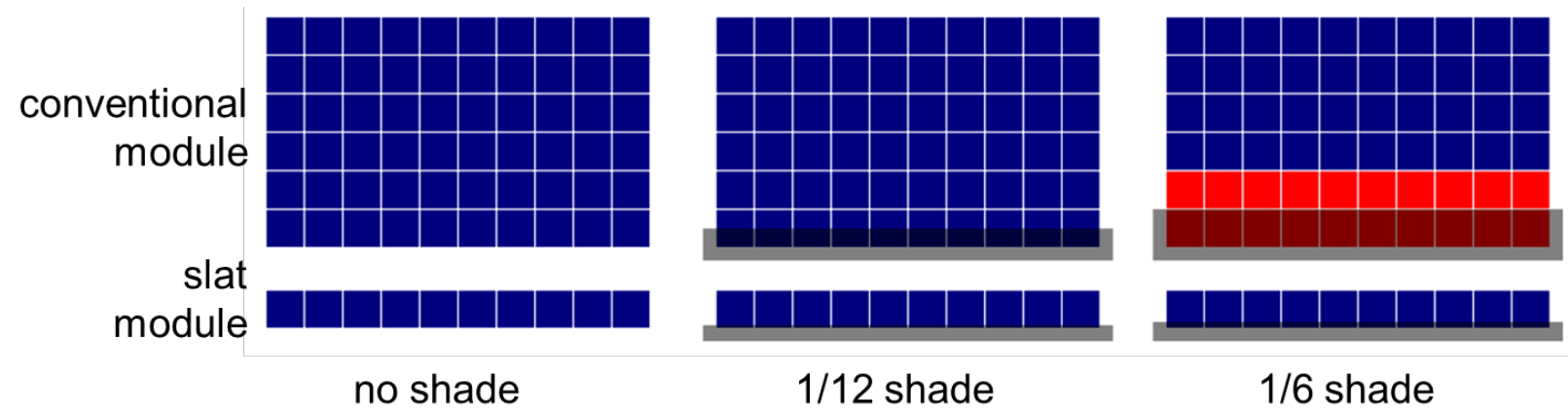

Figure 2. Shadow performance comparison of conventional module and PV Slat module, with red denoting cells rendered inactive because their bypass diode is activated

\subsection{Performance Simulation Method}

Established PV performance simulation tools, such as the System Advisor Model (SAM), include models for row-to-row shadows. However, these models are not yet compatible with the special geometry of slat modules. We used in-house shadow-modeling software to compare conventional module rooftop PV systems with slat module systems.

For a full year of hourly meteorological data, we calculated the pattern of illumination at the surface of both conventional and slat modules. This illumination pattern included the effects of diffuse irradiance reaching the portion of the module in shadow, excluding the portion of the sky blocked by other modules. We used the assumption, validated by experiment, that the electrical performance of a c-Si solar cell under nonuniform illumination matches its performance under uniform illumination of the same average intensity. With the additional assumption of linear superposition of I-V curves, we were able to determine electrical performance under each illumination condition and arrive at an annual yield metric for each candidate system.

We simulated candidate systems of conventional and slat modules with tilts ranging from $5^{\circ}$ to $40^{\circ}$, spacing ranging from very close to very far, and in locations including Kansas City, Missouri (which has relatively moderate insolation), Seattle, Washington (low insolation), and Daggett, California (high insolation). In all, more than 400 simulations were performed. Figure 3 displays a subsample of simulated system geometries. 
The conventional modules used in the simulation were $15.9 \%$-efficient multicrystalline silicon modules, and slat modules were simulated using the same efficiency. In line with conventional rooftop system geometry, the conventional system's modules were installed in landscape orientation, with a slant height (measured along the module surface) of about $1 \mathrm{~m}$. Each slat in the slat modules had a slant height of about $1 / 6 \mathrm{~m}$, reflecting the fact that slats have only one row of cells instead of six. When considering the effect of spacing and tilt on shadows, the inactive upper margin of the module becomes important, because it casts a shadow but does not produce electricity. We assumed the conventional module had an upper margin of $17 \mathrm{~mm}$, and the slat module had a margin of $7 \mathrm{~mm}$.

Commercial roofs, the target installation site for slat modules, are of fixed area. Systems designed for commercial roofs are often designed not to minimize LCOE, but to maximize capacity or reach a particular capacity target. As a reference system at each site, we used a 200$\mathrm{kW}$ commercial roof system. Based on this system size, we ignored the effects of the exceptional shadows on the front row of modules and on modules at the edges of the array. Using a common rule of thumb, the reference systems were designed to have no row-to-row shadows from 9:00 am to 3:00 pm. All other systems we considered were designed to fit into the same area as this reference system.

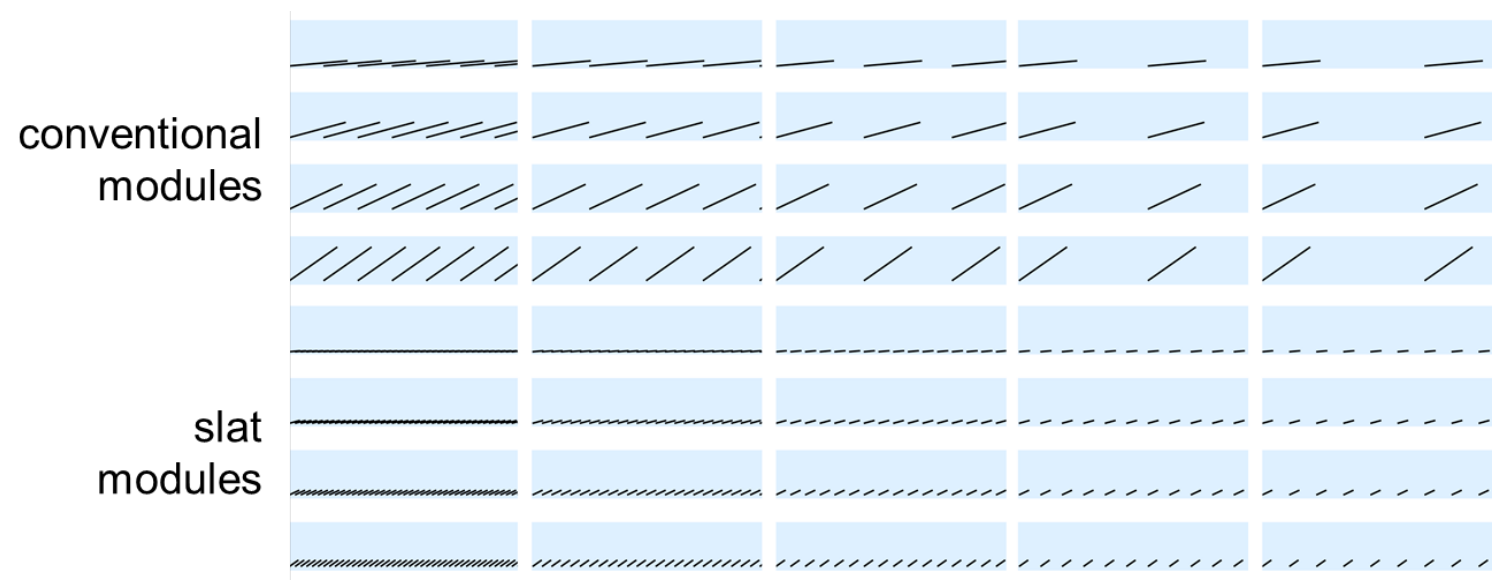

Figure 3. Simple diagrams of a subsample of simulated system geometries, showing the tilt angle and relative spacing for a range of candidate systems

\subsection{Performance Simulation Results}

We considered several systems occupying the same area as the reference system. We first considered conventional $5^{\circ}$-tilt systems with different row spacings, yielding systems with a range of direct current (DC) capacities. We then chose the minimum-capacity slat system, optimized for tilt and spacing, having the same annual energy production as the conventional system. In most cases, the slat system could produce the same annual energy yield with a smaller capacity, meaning a smaller number of modules or cells. We refer to the amount of this difference as the "capacity discount" for an equal-energy system. The capacity discount is plotted as a function of conventional system size in Figure 4. In some locations, the capacity discount is slightly negative for a range of systems. This is due in part to the inactive top margin of the slat occupying a larger fraction of the slat's height compared with the conventional module's margin. In a comparison of modules with no inactive margin, we found that the slat system capacity discount is always positive. In addition, the capacity discount is always positive 
in Seattle, because the smaller contribution of direct sunlight in this location weakens the effect of row-to-row shadows.

Three example equal-energy pairs of systems from the Kansas City curve in Figure 4 are shown with greater detail in Figure 5. As shown, an optimal slat system can produce the same amount of energy as a higher-capacity conventional system covering the same area because of its higher tilt and greater relative spacing. A $20^{\circ}$ tilt, for example, would be infeasible in most conventional roof-mounted systems owing to high wind loading and shade losses.

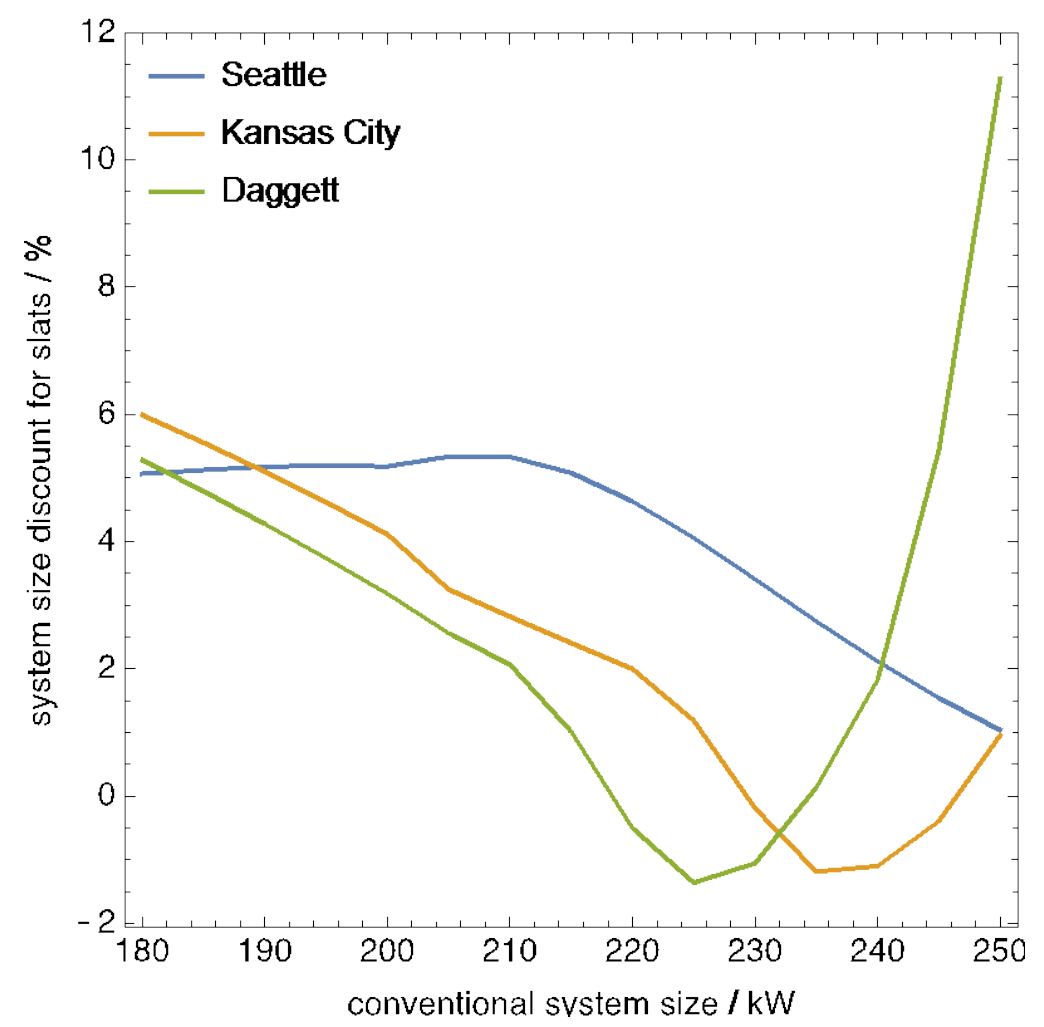

Figure 4. Capacity discount for a tilt- and spacing-optimized slat module system, as a function of conventional system size with $5^{\circ}$ tilt and spacing optimized for a fixed building size

\begin{tabular}{|c|c|c|c|c|c|c|}
\hline conventional system & tilt & capacity $(\mathrm{kW})$ & slat system & tilt & capacity & canacity diccount (\%) \\
\hline - & -5 & 180 & & 23 & 169 & 6 \\
\hline 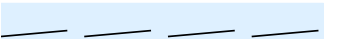 & 5 & 200 & 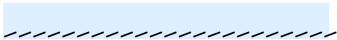 & 20 & 192 & 4 \\
\hline 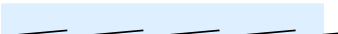 & 5 & 220 & & 16 & 216 & 2 \\
\hline
\end{tabular}

Figure 5. Example conventional systems with $5^{\circ}$ tilt and spacing optimized for a fixed building size compared with tilt- and spacing-optimized slat systems that produce the same amount of energy as the conventional systems but with smaller capacities, in Kansas City 


\section{Wind Tunnel Testing of PV Slat Modules}

NREL contracted CPP, Inc. to determine wind loads on PV Slat roof-mounted solar racking systems in a CPP boundary-layer wind tunnel. A scale model of an array was tested on scale models of three differently sized flat-roofed buildings. We later used the results in our cost calculations.

\subsection{Methods}

The wind tunnel study was conducted in accordance with the wind tunnel test procedures described in Chapter 31 of American Society of Civil Engineers/Structural Engineering Institute (ASCE/SEI) 7-10 (also meeting the requirements of ASCE/SEI 7-05), and in accordance with the specifications of ASCE/SEI 49-12 (ASCE 2006, ASCE 2012, ASCE 2013). Additional information concerning wind loading on roof-mounted PV systems can be found in the Structural Engineers Association of California's (SEAOC's) PV2 guidelines (SEAOC 2012). The CPP (2017) report, which is available from NREL upon request, conforms with the SEAOC PV2 method.

Forces applicable to the design of the ballasting/attachment of the NREL PV Slat modules were determined using a high-frequency balance (HFB) method, in which the aerodynamic loads are measured in the form of lift and drag on a rigid model mounted on an instrumented balance. Two arrays of seven rows of four modules were constructed with a tilt of $19^{\circ}$ (slat spacing of $219 \mathrm{~mm}$ ) and a tilt of $12^{\circ}$ (slat spacing of $191 \mathrm{~mm}$ ) at a scale of 1:20 (Figure 6). The HFB model was made with stereo-lithography to accommodate the small size of the slat modules. The array was offset from the roof edge by approximately $1 \mathrm{M}(3 \mathrm{ft})$ (at full scale).

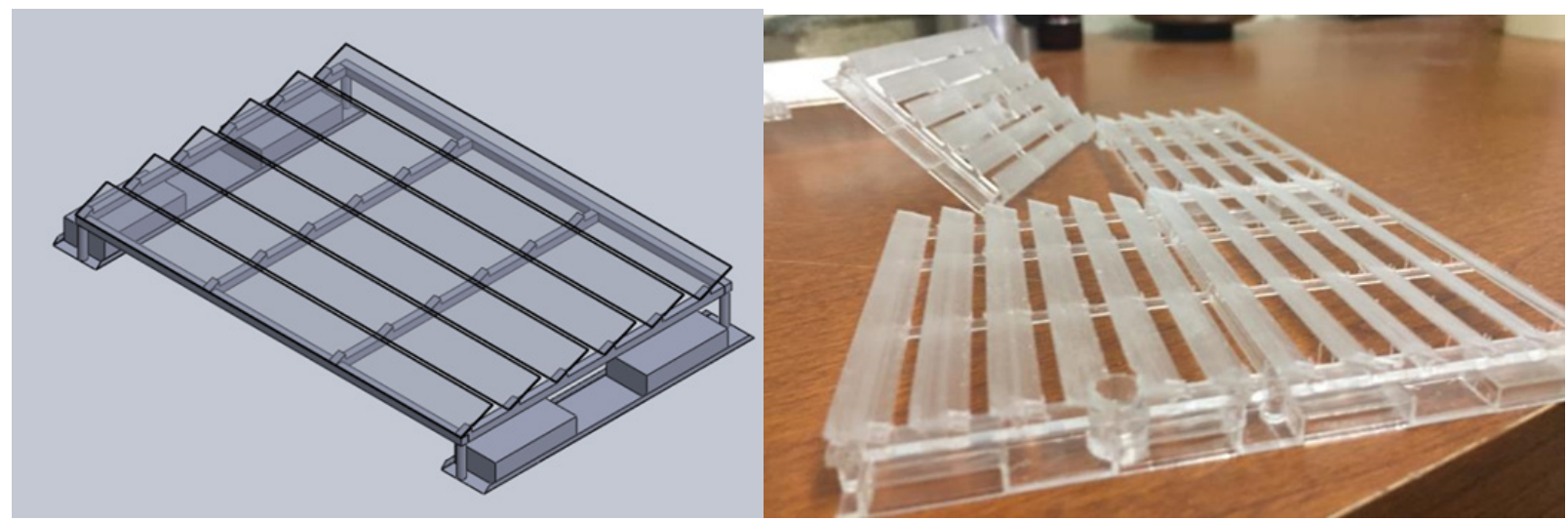

Figure 6. Three-dimensional model of slat module (left) and physical model used in wind tunnel test (right)

Photo by Otto VanGeet, NREL

\subsection{Results}

SEAOC's PV2 guidelines have four zones representing how the power of the wind vortices diminishes with distance from the corners of the buildings (Figure 7). The zones start with Zone 3 at the building corners, representing the worst effect of the corner vortices. Zone 2 covers the rest of the building perimeter. Zone 1 continues into the roof, demonstrating the decaying effect of the vortices. Zone 0 represents the furthest zone in from the building edge and the lowest- 
magnitude loads expected on the roof, where the flow is travelling parallel to the roof surface. We tested the slat modules in Zones 2 and 3. Figure 8 shows the results in terms of lift coefficients as a function of normalized wind area.

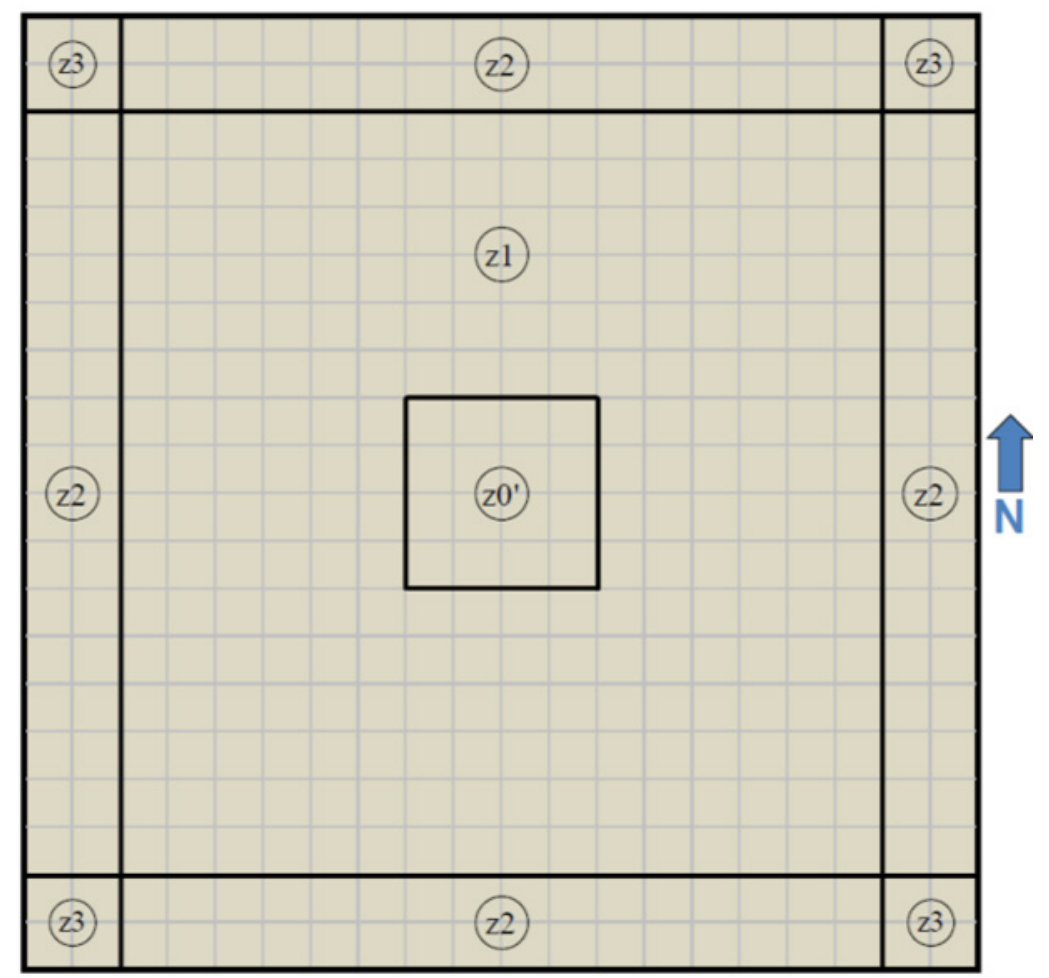

Figure 7. Roof zones, all wind directions from CPP (2017) Figure 3-1 


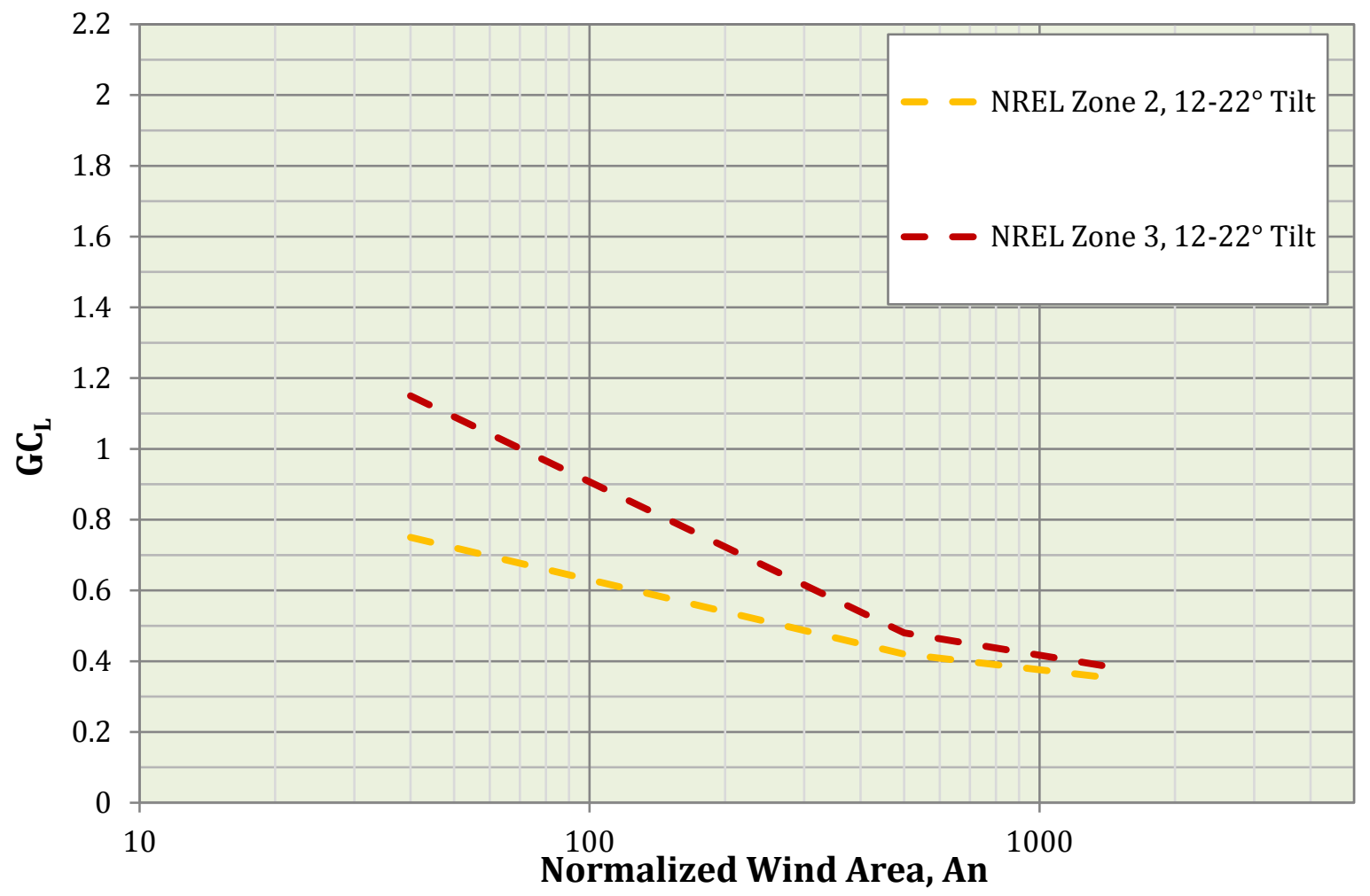

Figure 8. Lift coefficient (GCL) of PV Slat (NREL) modules a function of normalized wind area (CPP 2017)

Table 1 compares the results from Figure 8 using an "An" value of 50 with the ASCE design code for maximum wind force acting on ballasted rooftop PV arrays. In Zone 2, the force acting on the PV Slat modules is $41 \%$ lower than allowed by the design code. In Zone 3, it is $10 \%$ lower. These results are used for the cost modeling in Section 4.

Table 1. Lift Coefficients and Corresponding Forces Acting on Slat Modules in Wind Tunnel Test, with Comparison to ASCE Design Code

\begin{tabular}{|c|c|c|c|c|}
\hline Method & Where to apply & $\mathbf{G C}_{\mathrm{L}}$ & $\begin{array}{l}\text { Force } \\
\text { (lb/ft) }\end{array}$ & $\begin{array}{l}\text { Force reduction } \\
\text { compared to ASCE }\end{array}$ \\
\hline $\begin{array}{l}\text { Wind tunnel test: } \\
\text { Zone } 3\end{array}$ & Corner of roof & 1.13 & 264 & $10 \%$ \\
\hline $\begin{array}{l}\text { Wind tunnel test: } \\
\text { Zone } 2\end{array}$ & $\begin{array}{l}\text { Side between } \\
\text { two corners }\end{array}$ & 0.74 & 172 & $41 \%$ \\
\hline $\begin{array}{l}\text { Design code: } \\
\text { ASCE }\end{array}$ & Whole array & 1.25 & 292 & - \\
\hline
\end{tabular}




\section{Cost Modeling}

This section describes our cost model, including methods and assumptions (Section 4.1), and results (Section 4.2).

\subsection{Methods and Assumptions}

\subsubsection{Module Cost Models}

We performed bottom-up manufacturing cost analysis to estimate the costs associated with the slat module compared with a traditional c-Si PV module. The Design for Manufacturing and Assembly (DFMA) software tool was used to calculate the costs associated with the structural components of the slat module, including the frame, legs, and slat supports. ${ }^{2}$ Figure 9 and Figure 10 show the overall dimensions of the PV Slat frame and the PV Slat support, respectively. Using this approach, we compared the costs of a metal-only structure to one with the slat frame made from extruded polymer (polymethyl methacrylate [PMMA] with ultraviolet [UV] stabilizers), which is suitable for outdoor use and expected to provide the required structural integrity.

We also modeled the costs of injection molding the entire frame plus slat support structure as one unit using polymer materials. However, we found this approach would not be cost-effective and - for the dimensions of the module shown in Figure 9-would be challenging from a manufacturing feasibility perspective.

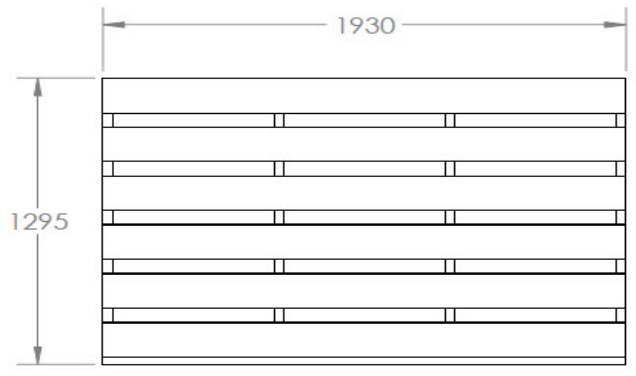

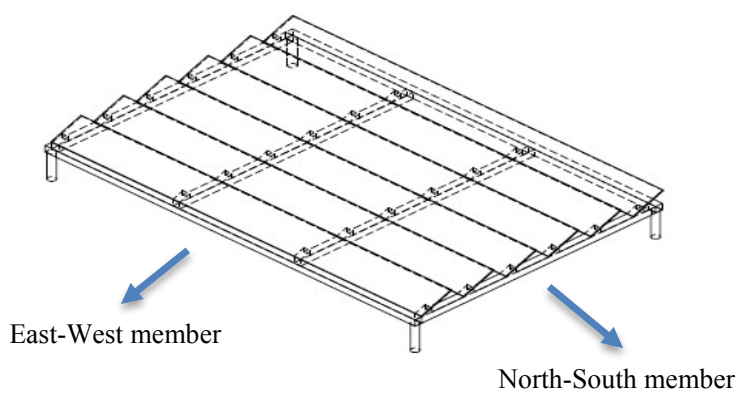
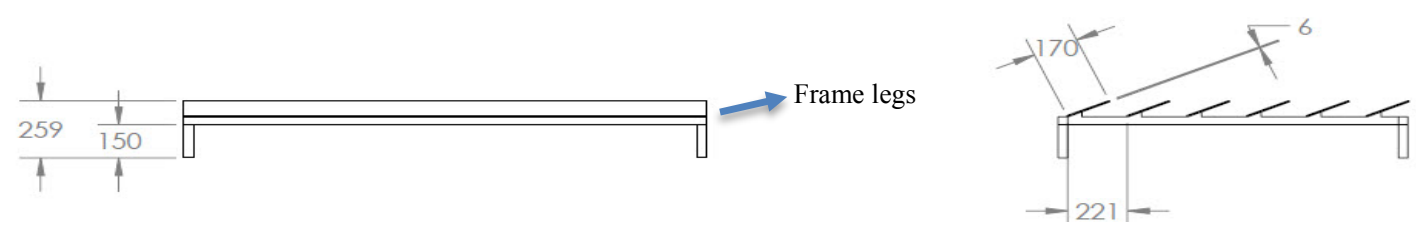

Figure 9. Overall dimensions for PV Slat frame used in manufacturing analysis (in millimeters)

\footnotetext{
${ }^{2}$ See http://www.dfma.com/software/dfma.asp for information about DFMA.
} 

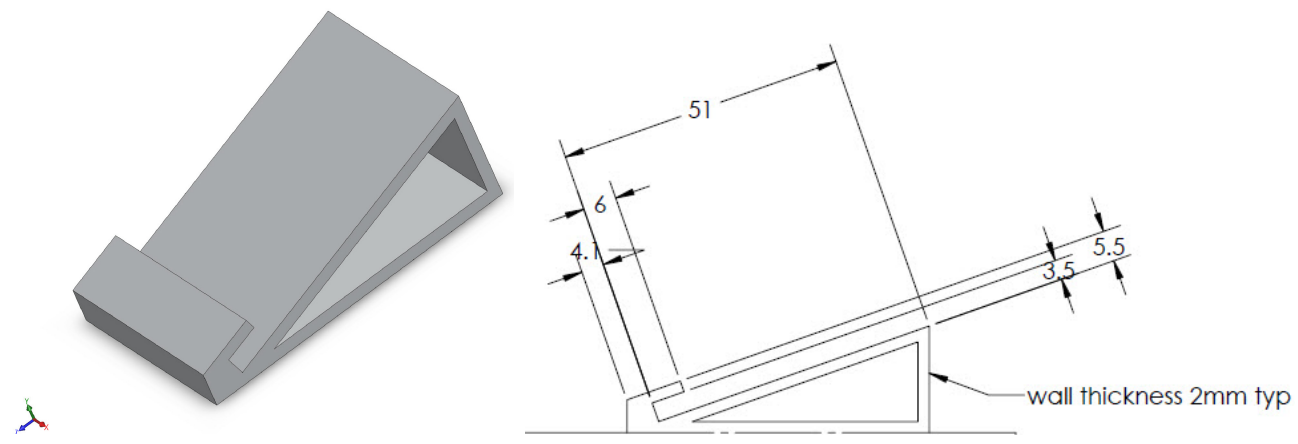

Figure 10. Computer-aided design model (left) and general dimensions for aluminum (Al) PV Slat supports (in millimeters)

The module shown in Figure 9 represents a 350-W, 72-cell module. To estimate potential costs at high volume and compare with incumbent technology, we assumed a production volume of $500 \mathrm{MW} / y e a r$, approximately equivalent to a demand of 1.43 million modules/year.

To estimate total module manufacturing cost per watt, the modeled costs for these structural components were incorporated into a modified version of NREL's 2017 bottom-up baseline model for incumbent technology based on standard c-Si 72-cell passivated emitter and rear cells (PERC) modules manufactured in Southeast Asia (Fu et al. 2017). We matched assumptions between the slat module and baseline cases with regard to manufacturing location (Southeast Asia) and markup above manufacturing costs to enable a consistent comparison.

\subsubsection{System Cost Models}

We used NREL's established bottom-up approach (Fu et al. 2017) to model installed system costs. In general, we attempted to model the typical installation techniques and business operations from an installed-cost perspective. Costs were represented from the perspective of the installer, thus all hardware costs represent the price at which components are purchased by the developer/installer, not accounting for preexisting supply agreements or other contracts. Costs also represent the sales price paid to the installer, including profit in the cost of the hardware, along with the profit the installer receives, as a separate cost category.

\subsubsection{LCOE Calculations}

The present value of annualized cost (numerator of the LCOE equation) was calculated using SAM version 2017.9.5. The model used for NREL's 2017 benchmark for a 200-kW commercial rooftop system in Kansas City (Fu et al. 2017) was modified to reflect total installed system costs for the system with slat modules, calculated as described in Section 4.1.2. All other financial and system assumptions (direct to alternating current ratio, discount rate, etc.) were the same as in the baseline model. The federal investment tax credit was not included, nor were any local or state incentives.

Energy yield values for Kansas City from Section 2 were used as the first-year energy yield in the LCOE calculations. As in the baseline case, a degradation rate of $0.75 \% / y e a r$ was used. The discounted annual energy yield was then calculated for the denominator of the LCOE equation. 


\subsection{Results}

\subsubsection{Module Cost}

Table 2 summarizes the results from DFMA comparing an all-metal structure and a structure with a polymer frame. The cost for attaching the slat holders (screws and washers for the allmetal case, adhesive for the hybrid polymer/metal case) is not included here, but it is accounted for in the overall manufacturing costs presented below.

As seen in Table 2, the manufacturing cost of the slat structural components is much lower for the all-metal design than for the hybrid polymer/metal design at these scales. The component dimensions for the polymer/metal hybrid case were chosen conservatively to ensure required structural integrity in the absence of detailed mechanical modeling; further structural optimization might reduce the cost. The hybrid design may have benefits derived from its lighter weight (e.g., system cost benefits, ability to install on more weight-constrained rooftops), but we did not quantify such benefits, and it is unclear whether they would offset the large increase in the slat structure manufacturing costs to result in a lower total installed system cost or broader adoption. Because the all-metal structure was much more cost-effective, this design is used for our module, system, and LCOE cost results in the remainder of this section. 
Table 2. Summary of Slat Structure Manufacturing Costs for Two Different Structure Options (not including cell costs or module-assembly costs)

\begin{tabular}{|c|c|c|c|c|c|}
\hline Part & $\begin{array}{l}\text { Material used } \\
\text { and shape }\end{array}$ & $\begin{array}{l}\text { Part dimension } \\
\text { (mm, width } x \\
\text { length } x \text { height) }\end{array}$ & $\begin{array}{l}\text { Number } \\
\text { for one } \\
350-W \\
\text { module }\end{array}$ & $\begin{array}{l}\text { Production } \\
\text { volume for } \\
\sim 1.43 \text { million } \\
\text { modules }\end{array}$ & $\begin{array}{l}\text { Expected } \\
\text { manufacturing } \\
\text { cost for parts } \\
\text { needed for } \\
\text { module (\$) }\end{array}$ \\
\hline \multicolumn{6}{|c|}{ Structure Option 1: All-Metal Slat Structure } \\
\hline $\begin{array}{l}\text { East-West } \\
\text { Frame } \\
\text { Members }\end{array}$ & $\begin{array}{l}\text { Generic Al alloy, } \\
\text { extruded custom } \\
\text { shape }\end{array}$ & $\begin{array}{l}1930 \text { mm length, } \\
\text { cross-sectional } \\
\text { dimensions same as } \\
\text { a standard PV } \\
\text { module frame }\end{array}$ & 2 & $2,860,000$ & $\$ 4.14$ \\
\hline $\begin{array}{l}\text { North-South } \\
\text { Frame } \\
\text { Members }\end{array}$ & $\begin{array}{l}\text { Generic Al alloy, } \\
\text { extruded custom } \\
\text { shape }\end{array}$ & $\begin{array}{l}1195 \mathrm{~mm} \text {, cross- } \\
\text { sectional dimensions } \\
\text { same as a standard } \\
\text { PV module frame }\end{array}$ & 4 & $5,720,000$ & $\$ 4.95$ \\
\hline $\begin{array}{l}\text { PV Slat } \\
\text { Supports }\end{array}$ & $\begin{array}{l}\text { Generic Al alloy, } \\
\text { extruded custom } \\
\text { shape }\end{array}$ & $\begin{array}{l}35 \mathrm{~mm} \times 54 \mathrm{~mm} \times \\
19 \mathrm{~mm} \text { (thickness, } \mathrm{t} \\
=2 \mathrm{~mm} \text { ) }\end{array}$ & 24 & $34,320,000$ & $\$ 2.88$ \\
\hline \multirow[t]{2}{*}{ Legs } & $\begin{array}{l}\text { Generic Al alloy } \\
\text { machined from } \\
\text { stock, tube }\end{array}$ & $\begin{array}{l}50 \mathrm{~mm} \text { (outer } \\
\text { diameter, OD) } \times 3 \\
\mathrm{~mm}(\mathrm{t}) \times 150 \mathrm{~mm}\end{array}$ & 4 & $5,720,000$ & $\$ 4.72$ \\
\hline & & & & $\begin{array}{l}\text { Total } \\
\text { Structure } \\
\text { Cost }\end{array}$ & $\$ 16.69$ \\
\hline \multicolumn{6}{|c|}{ Structure Option 2: Polymer/Metal Hybrid Slat Structure } \\
\hline $\begin{array}{l}\text { East-West } \\
\text { Frame } \\
\text { Members }\end{array}$ & $\begin{array}{l}\text { PMMA with UV } \\
\text { stabilizer, box tube }\end{array}$ & $\begin{array}{l}1930 \mathrm{~mm} \times 60 \mathrm{~mm} \\
\text { outer profile }(\mathrm{t}=5 \\
\mathrm{mm}) \times 50 \mathrm{~mm} \text { (outer } \\
\text { profile, } \mathrm{t}=5 \mathrm{~mm})\end{array}$ & 2 & $2,860,000$ & $\$ 48.10$ \\
\hline $\begin{array}{l}\text { North-South } \\
\text { Frame } \\
\text { Members }\end{array}$ & $\begin{array}{l}\text { PMMA with UV } \\
\text { stabilizer, box tube }\end{array}$ & $\begin{array}{l}1195 \mathrm{~mm} \times 50 \mathrm{~mm} \\
\text { outer profile }(\mathrm{t}=5 \\
\mathrm{mm}) \times 50 \mathrm{~mm} \text { (outer } \\
\text { profile, } \mathrm{t}=5 \mathrm{~mm})\end{array}$ & 4 & $5,720,000$ & $\$ 44.20$ \\
\hline $\begin{array}{l}\text { PV Slat } \\
\text { Supports }\end{array}$ & $\begin{array}{l}\text { PMMA with UV } \\
\text { stabilizer, extruded } \\
\text { custom shape }\end{array}$ & $\begin{array}{l}35 \mathrm{~mm} \times 54 \mathrm{~mm} \times \\
19 \mathrm{~mm}(\mathrm{t}=5 \mathrm{~mm})\end{array}$ & 24 & $34,320,000$ & $\$ 2.88$ \\
\hline \multirow[t]{2}{*}{ Legs } & $\begin{array}{l}\text { Generic Al alloy } \\
\text { machined from } \\
\text { stock, tube }\end{array}$ & $\begin{array}{l}50 \mathrm{~mm}(\mathrm{OD}) \times 3 \mathrm{~mm} \\
(\mathrm{t}) \times 150 \mathrm{~mm}\end{array}$ & 4 & $5,720,000$ & $\$ 7.36$ \\
\hline & & & & $\begin{array}{l}\text { Total } \\
\text { Structure } \\
\text { Cost }\end{array}$ & $\$ 102.55$ \\
\hline
\end{tabular}

Rolling the estimates for the all-metal slat structure costs into the complete module manufacturing cost model, we obtained a total module manufacturing cost of $\$ 0.43 / \mathrm{W}$ (DC) and estimated price (with the same overhead costs and margin as assumed for the baseline c-Si module) of $\$ 0.47 / \mathrm{W}_{\text {(DC) }}$. In contrast, the manufacturing cost is $\$ 0.31 / \mathrm{W}_{\text {(DC) }}$ and the price is $\$ 0.35 / \mathrm{W}_{(\mathrm{DC})}$ for the baseline 72-cell PERC module. Figure 11 shows the step-by-step cost 
breakdown for the slat modules, noting where costs are added compared with the baseline modules. The largest cost increase $\left(\$ 0.087 / \mathrm{W}_{(\mathrm{DC})}\right)$ is due to the use of five additional junction boxes (j-boxes), because the slat module contains six slats, and each requires its own $\mathrm{j}$-box. The slat module structural components (for the all-metal design) add $\$ 0.034 / \mathrm{W}_{\text {(DC) }}$.

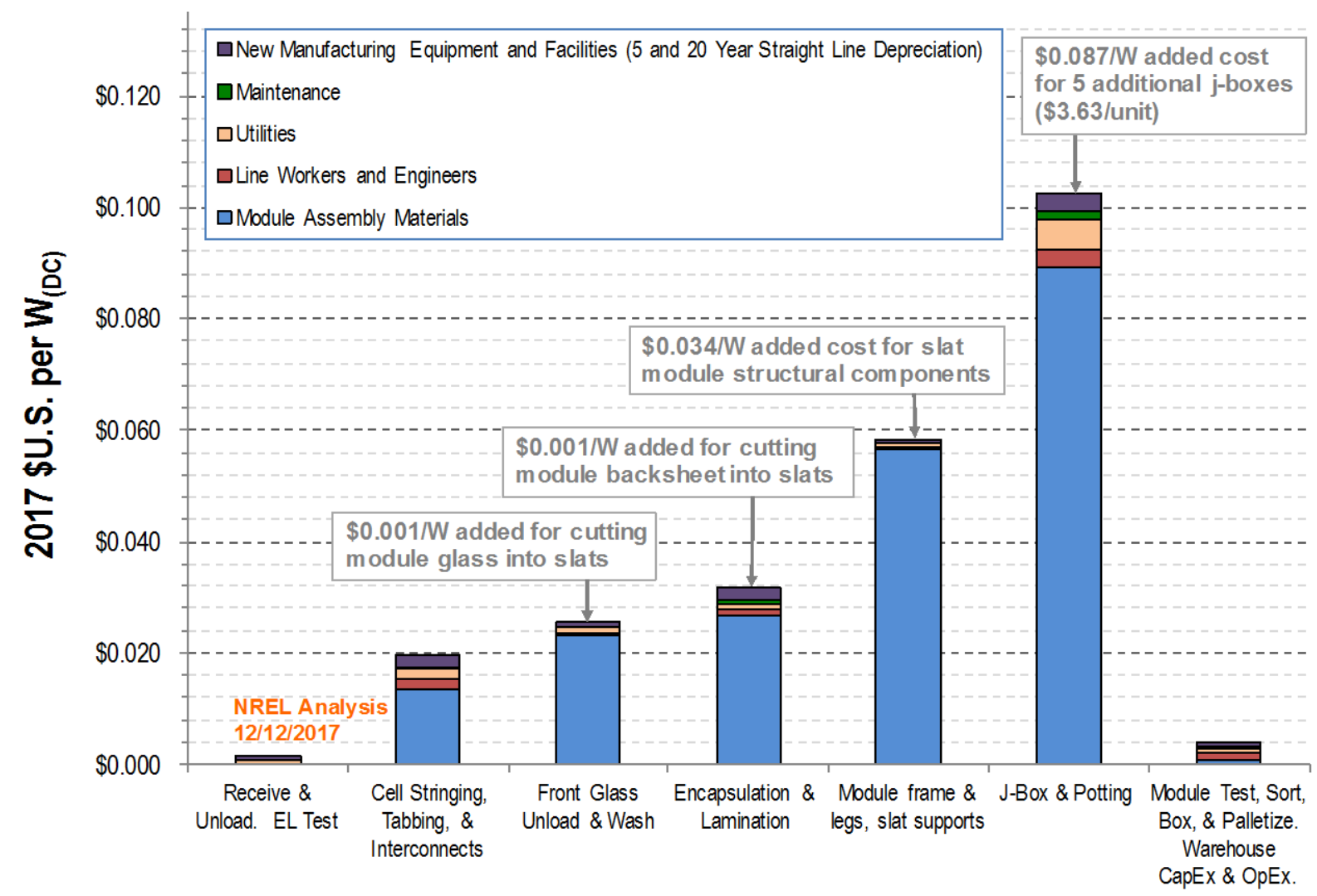

Figure 11. Step-by-step manufacturing costs for the slat module assembly (with the all-metal structure) using monocrystalline PERC solar cells, assuming 500-MW annual production volume and manufacturing in urban China, $72\left(239 \mathrm{~cm}^{2}\right)$ PERC cells at $21.5 \%$ efficiency, $350 \mathrm{~W}$ per module

\subsubsection{Installed System Cost}

The installed system cost modeling results are summarized in Table 3. The baseline design considers the traditional ballasted system and its weight, which costs approximately $\$ 82.50$ per module. When a slat module is used, the racking system is instead integrated into the module structure, and the ballast racking system is no longer needed. In addition, the slat system's simpler installation process reduces labor time and related overhead. These factors result in BOS, labor, and other cost savings of $\$ 0.14-0.17 / \mathrm{W}$, which exceed the $\$ 0.12 / \mathrm{W}$ price premiums for the slat modules. Although there is considerably more uncertainty associated with the novel slat module and system costs than with the incumbent module technology costs, this analysis suggests that the slat module design could be cost-effective on an installed-cost basis.

As shown in Table 3, we calculated slat-module installed system costs for Zones 2 and 3 to investigate the tradeoffs between wind loading and cost. The cost is lower in Zone 2, because that zone's lower lift coefficient entails lower structural material requirements and thus lower BOS and labor costs. Note that the baseline c-Si module case also assumes installation in Zones 2 and 3. 
Table 3. Installed System Costs for a 200-kW Commercial Rooftop System in Kansas City

\begin{tabular}{|c|c|c|c|c|c|c|}
\hline $\begin{array}{l}\text { Module } \\
\text { Design }\end{array}$ & $\begin{array}{l}\text { Module } \\
\text { Price } \\
\left(\$ / \mathbf{W}_{(\mathrm{DC})}\right)\end{array}$ & $\begin{array}{l}\text { Inverter } \\
\left(\$ / W_{(D C)}\right)\end{array}$ & $\begin{array}{l}\text { BOS (structural } \\
\text { and electrical) } \\
\left(\$ / W_{(D C)}\right)\end{array}$ & $\begin{array}{l}\text { Labor } \\
\left(\$ / W_{(D C)}\right)\end{array}$ & $\begin{array}{l}\text { Other (developer } \\
\text { overhead, profit, } \\
\text { sales tax) }\left(\$ / W_{(D C)}\right)\end{array}$ & $\begin{array}{l}\text { Total } \\
\left(\$ / \mathbf{W}_{(\mathrm{DC})}\right)\end{array}$ \\
\hline $\begin{array}{l}\text { Baseline c-Si } \\
\text { PERC }\end{array}$ & 0.35 & 0.13 & 0.30 & 0.16 & 0.86 & 1.80 \\
\hline $\begin{array}{l}\text { Slat Module (all } \\
\text { in Zone 3) }\end{array}$ & 0.47 & 0.13 & 0.18 & 0.16 & 0.84 & 1.77 \\
\hline $\begin{array}{l}\text { Slat Module (all } \\
\text { in Zone 2) }\end{array}$ & 0.47 & 0.13 & 0.17 & 0.15 & 0.83 & 1.75 \\
\hline
\end{tabular}

\subsubsection{LCOE}

Table 4 summarizes the LCOE results for the baseline/standard c-Si PERC 72-cell module and the slat module in the two configurations with the modules all in Zone 2 or all in Zone 3 . Both slat module options result in a lower LCOE compared with the baseline case owing to lower installed system costs and the increased energy yield. Again, although these results entail substantial uncertainty because of the novelty of slat modules, they suggest that the slat-module design could be cost-effective on an LCOE-basis as well.

Table 4. Summary of LCOE Results for a 200-kW Commercial Rooftop System in Kansas City

\begin{tabular}{|c|c|c|c|c|}
\hline Module Design & $\begin{array}{l}\text { First-Year Energy } \\
\text { Yield (kWh/kW(DC) }\end{array}$ & $\begin{array}{l}\text { Capacity } \\
\text { Factor }\end{array}$ & $\begin{array}{l}\text { Total Installed } \\
\text { System Cost }\left(\$ / W_{(D C)}\right)\end{array}$ & $\begin{array}{l}\text { Nominal LCOE } \\
\text { ( } / / \mathrm{kWh})\end{array}$ \\
\hline $\begin{array}{l}\text { Baseline/Standard } \\
\text { c-Si PERC }\end{array}$ & 1,415 & $16.15 \%$ & $\$ 1.80$ & 14.08 \\
\hline $\begin{array}{l}\text { Slat Module (all in } \\
\text { Zone 3) }\end{array}$ & 1,448 & $16.43 \%$ & $\$ 1.77$ & 13.57 \\
\hline $\begin{array}{l}\text { Slat Module (all in } \\
\text { Zone 2) }\end{array}$ & 1,448 & $16.43 \%$ & $\$ 1.75$ & 13.45 \\
\hline
\end{tabular}




\section{References}

ASCE (American Society of Civil Engineers). 2013. Minimum Design Loads for Buildings and Other Structures. ASCE/SEI 7-10. Reston, VA: ASCE.

ASCE (American Society of Civil Engineers). 2012. Wind Tunnel Testing for Buildings and Other Structures. ASCE/SEI 49-12. Reston, VA: ASCE.

ASCE (American Society of Civil Engineers). 2006. Minimum Design Loads for Buildings and Other Structures. ASCE/SEI 7-05. Reston, VA: ASCE.

CPP (Cermak, Peterka, Petersen). 2017. Wind Tunnel Tests and Load Analysis for NREL PV Slat Modules. CPP Project 9711. Fort Collins, CO: CPP.

Fu, R., D. Feldman, R. Margolis, M. Woodhouse, and K. Ardani. 2017. U.S. Solar Photovoltaic System Cost Benchmark: Q1 2017. NREL/TP-6A20-68925. Golden, CO: National Renewable Energy Laboratory. https://www.nrel.gov/docs/fy17osti/68925.pdf

SEAOC (Structural Engineers Association of California). 2012. Wind Design for Low-Profile Solar Photovoltaic Arrays on Flat Roofs. PV2-2012. Sacramento: SEAOC. 